\title{
TEMPERATURE PREDICT OF AERATION TANK WALLS FOR BIOLOGICAL WASTEWATER TREATMENT SUBSYSTEM OF HAMDAN STATION
}

\author{
Akeel M. Ali Morad \\ Department of Fuel and Energy ${ }^{l}$ \\ akeel@stu.edu.iq \\ Alya Aqeel Mohammed \\ Department of Environmental and Pollution ${ }^{l}$ \\ alayaalrefee@stu.edu.iq \\ Angham Omeer Sahi \\ Department of Environmental and Pollution ${ }^{1}$ \\ angham.omeer@stu.edu.iq \\ Ali Khalid Shaker Al-Sayyab \\ Department of Thermal Mechanics \\ Castellon de la Plana \\ 11 C/Union, Castellon, Spain, 12004 \\ ali.alsayyab@stu.edu.iq \\ ${ }^{1}$ Engineering Technical College \\ Southern Technical University \\ Alzubair Highway str. - In front of Basra Sport City, Basra-Iraq, 61001
}

\begin{abstract}
A heat transfer modeled for predicting the wall temperature of aeration tank in a biological wastewater treatment subsystem of Hamden station is presented. The method to treatment employed depending upon the pollutants in wastewater and extent to which it is desired to eliminate them in order to congregate required standards of water quality. Several heat gain and loss mechanisms concerned to develop of the model of temperature computer includes heat gains through conduction and radiation. While the heat losses referred to convection and radiation. It classified radiation heat transfer and biological reaction as a gained heat, while classifying the rate of evaporation, aerator, and wind velocity as lost heat.

This study relied on a previous study, and based on the assumptions that have been identified so that a model development can be obtained to calculate the surface temperature of the wall of the aeration tank in a biological treatment system. The operational, weather and temperature data were to be registered from Iraqi weather forecast- Basra Airport. To obtain reliable results, the model was simulated using the STELLA software v.9.02, which gave accurate results in determining the parameters that affect the tank wall temperature changes. The STELLA software is Model calibration and considers as a dynamics language because of STELLA is software for graphic and dynamic simulation for the wall temperature of aeration tank. The results have shown a good accuracy and increment between the production walls temperatures with average ranged about ( $0.2 \%)$ of present work. The model shows the sensitivity through set of precious five parameters like organic removal rate, ambient air temperature, wind velocity, air relative humidity, and the wall effective area of the aeration tank.
\end{abstract}

Keywords: aeration tank wall temperature, parameters affecting, biological treatment, STELLA software used.

DOI: $10.21303 / 2461-4262.2021 .001706$

\section{Introduction}

The water pollutants become from several portion, some of wasted from the municipals and some from industrials. These pollutants are primarily public health problems for entire world. Whole wastewater contains ecological constituents are enabled to treat biologically. The biological treatment process )aerobic and anaerobic( may be either fond of growth process with units like trickling filters or suspended growth processes with units like activated sludge process, aeration tanks, aerated lagoons, etc. All these processes take the lead of the facility of microorganisms to 
convert to organic wastes with stabilized and with energy compounds [1]. Through this converting process, heat energy conversion will occur as a result of this reaction. Thermal energy of this system could express through the temperature on the wall surface of any biological treatment system. The mechanism of heat realized due to the conversion wastes into organic wastes by microorganisms' was introduced by [2]. The efficient of biological wastewater treatment system is well studied and presents by $[3,4]$. These systems consist of aeration tank and clarifier as show in Fig. 1. The biological reactions produced temperature changes carried out from the enzyme rates of catalyzed reactions due to diffusion function. The aeration tank design is based on the tank's equilibrium temperature. This equilibrium temperature is depending on the environment temperature, which in turn is affected by the seasons of the year [5]. There is a temperature change between the aeration tank of biological wastewater and the surrounding air by means of heat transfer. These changes can conduction through the tank walls. While there is heat transfer by radiation which can cause by the influence of the temperature of the wastewater through solar radiation. From the movement of the air surrounding the tank and the presence of conductive and radiant heat transfer, it results in a transfer of heat by convection and evaporation into the surrounding air. From above, it can summarize four methods of heat transfer, namely heat transfer by conduction, radiation, convection, and finally evaporation. The first study presented these methods of heat transfer to the ventilation tank, taking into account the rate of daily change of temperature and air speed in addition to that month by [6].

A few studies have been published to calculate river water temperature to formulate a mathematical relationship. Some of these studies have found factors affecting the water temperature of rivers affected by air temperature and air speed [7, 8]. Some studies have found the rate of water supply in addition to temperature and air velocity parameters [9].

It has been proven that the biological reaction coefficient is affected by the change in the water temperature, especially for wastewater treatment, which is the time factor within the effect range due to the Oxygen Demand of (BOD and COD) $[10,11]$.

Unfortunately, there is no more published paper considered the simulation to estimate the temperature of the aeration tank with all heat transfer models.

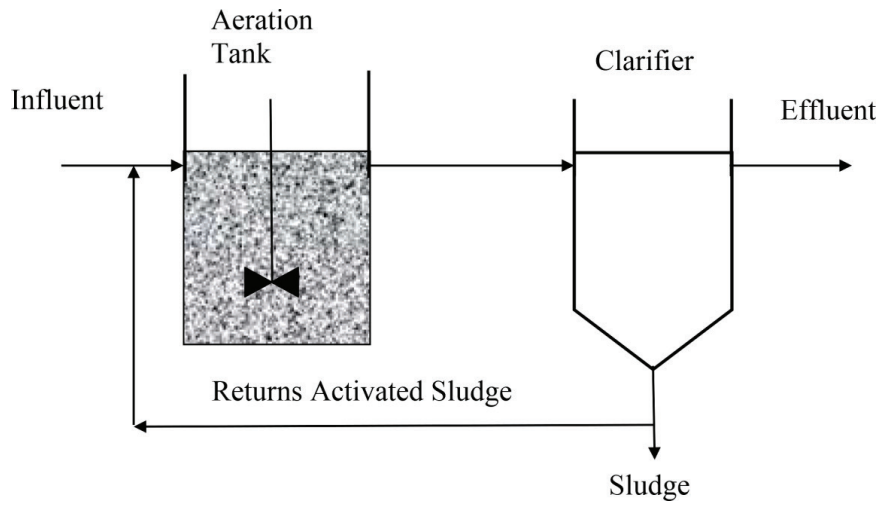

Fig. 1. Biological treatment system [2]

In this study aimed to show that all heat transfer models can be evaluated the temperature using dynamic software program for whole energies of heat which expected that gained, generated and rejected.

Recently, the Structural Thinking Experiential Learning Laboratory with Animation (STELLA v9.0.2) which well used for environmental implementations by [12].

\section{Mathematical Modeling}

In a biological wastewater treatment process shown in Fig. 1, aeration tank is the most important unit which is responsible for decomposition of all organic pollutants. The aeration tank is a rectangular with concrete walls; division of the aeration tank is covered underground and the rest is showing to the air above ground. To determine heat transfer models including conduction, 
convection, radiation and vaporization, all must be well thought-out. Fig. 2 showed the total energies of the aeration tank as:

$$
\rho C_{P} \dot{\forall}\left(T_{w}-T_{i}\right)=\sum H,
$$

where $\rho$ - wastewater density, $C_{P}$ - specific heat at constant pressure of wastewater, $\dot{\forall}$ - wastewater flow rate, $T_{w}$ - aeration tank wall temperature, and $T_{i}$ - wastewater influence temperature and $\sum H-$ total heat gained in aeration tank.

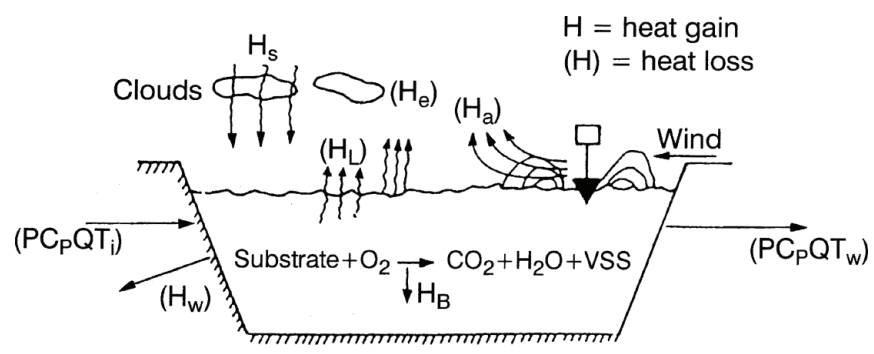

Fig. 2. Total energy modeled of aeration tank [6]

The expressed terms of total heat gained with various factors as presented by [6], it illustrated as:

$$
\sum H=H_{S}+H_{B}+H_{L}+H_{E}+H_{D}+H_{W},
$$

where $H_{S}$ - heat gained from solar radiation, $H_{B}$ - heat gained due to biological reaction, $H_{L}$ - heat loss by radiation from wastewater surface, $H_{E}$ - heat loss due to wastewater evaporation, $H_{D}$ - heat loss due to surface diffuser and $H_{W}$ - heat loss through tank walls.

The expressed of solar radiation gained presented by [13] as:

$$
H_{S}=\left(H_{S}\right)_{\text {averg }} A(1-0.0071 C)^{2},
$$

where $\left(H_{S}\right)_{\text {averg }}$ - the average solar radiation daily absorbed which registered from Iraqi weather forecast - Basra Airport, $A$ - the surface area of aeration tank and $C$ - the average fractional cloud cover factor from Iraqi weather forecast - Basra Airport.

The heat gained from biological reaction was presented the expression by [2],

$$
\begin{gathered}
H_{B}=1.8\left(S_{R}\right), \\
S_{R}=(N / P) \times 10^{d},
\end{gathered}
$$

where $S_{R}$ - the pollutants removal rate, most range of this rate is $(0.37$ and $3.3 \mathrm{Kcal} / \mathrm{gram}[3,4]$; $N$ - the number of bacterial in one part of dish, $P$ - the number of part dish ( $=4$ in current study), and $d$ is the dilution factor. The heat loss by radiation from the aeration tank surface is given by [5]:

$$
H_{L}=A\left[695 \times 10^{4}(1-\beta)+10.18 \times 10^{4}\left(T_{W}-T_{a}\right)+10.18 \times 10^{4}(1-\beta) T_{a}\right],
$$

where $\beta$ - the atmospheric radiation factor which calculated by [4] and will ranged from 0.76 to 0.95 , and $T_{a}$ - ambient air temperature from Iraqi weather forecast - Basra Airport.

The heat loss due to evaporation was modeled by [6] as:

$$
H_{E}=\left[1.145 \times 10^{6}(1-0.01 \varphi)+6.86 \times 10^{4}\left(T_{W}-T_{a}\right)\right] e^{\left(0.0504 T_{a}\right) C_{a}\left(A^{0.96}\right)},
$$

where $\varphi$ - the relative humidity of ambient air from Iraqi weather forecast - Basra Airport, $C_{a}$ - the wind velocity from Iraqi weather forecast - Basra Airport. 
The diffuser aeration heat transfer was suggested by [8] and developed by [6] due to assume the air and the water vapor is saturated, which represented as:

$$
H_{D}=8.64 \times 10^{4} \dot{\forall}_{a}\left[300\left(T_{W}-T_{a}\right)+2.91(1-0.0 \varphi) e^{\left(0.0604 T_{a}\right)+178\left(T_{W}-T_{a}\right) \times e^{\left(0.0604 T_{a}\right)}}\right] .
$$

The conduction heat transfer occurred through the walls of aeration tank and the bottom. Generally, the walls and the bottom constructed from the compounds materials, thus to calculate heat transfer through the walls and bottom should be depends on the inner surface temperature of the tank with outer surface temperature as well. The heat transfer can calculated as:

$$
H_{W}=A_{W} U\left(T_{W}-T_{a}\right)
$$

where $A_{W}$ - the effective wall area, $U$ - overall heat transfer coefficient. Empirically, the value of $U$ is presented by [6] which ranged from $\left(10\right.$ to $20 \mathrm{kcal} / \mathrm{cm}^{2}$-day- $\left.{ }^{\circ} \mathrm{C}\right)$. Now, all heat transferred models found, it can compute the aeration tank wall temperature from below:

$$
\begin{gathered}
T_{W}=T_{i}+\left(H_{S}+H_{B}+H_{E}+H_{D}+H_{W}\right) /\left(\rho C_{P} \dot{\forall}_{a}\right), \\
M P E=\frac{O B S-O U T}{O B S} \cdot 100,
\end{gathered}
$$

where $M P E$ - the mean present error, $O B S$ - observation data, $O U T$ - output data from the

\begin{tabular}{|c|c|c|c|c|c|c|c|c|c|}
\hline \multirow[t]{2}{*}{ Month } & \multirow{2}{*}{$\begin{array}{c}\text { Influent } \\
\text { Rate } \\
\text { (m²/day) }[15]\end{array}$} & \multirow{2}{*}{$\begin{array}{l}\text { Organic } \\
\text { Load } \\
(\mathrm{kg} / \mathrm{day})\end{array}$} & \multirow{2}{*}{$\begin{array}{c}\text { Influent } \\
\text { wastewater } \\
\text { temp. }\left({ }^{\circ} \mathrm{C}\right)[15]\end{array}$} & \multicolumn{2}{|c|}{$\begin{array}{l}\text { Ambient air } \\
\text { temp. }\left({ }^{\circ} \mathrm{C}\right)\end{array}$} & \multirow{2}{*}{$\begin{array}{l}\text { Wind } \\
\text { speed } \\
(\mathrm{m} / \mathrm{sec})\end{array}$} & \multirow{2}{*}{$\begin{array}{l}\text { Air relative } \\
\text { humidity } \\
(\%)\end{array}$} & \multirow{2}{*}{$\begin{array}{l}\text { Solar radiation } \\
\text { (Kcal/m² day) }[14]\end{array}$} & \multirow{2}{*}{$\begin{array}{l}\text { Cloudiness } \\
\text { factor }\end{array}$} \\
\hline & & & & Min & Max & & & & \\
\hline 1 & 21,200 & 24,400 & 11 & 7.8 & 19.4 & 4 & 67 & 3.2 & 9.5 \\
\hline 2 & 20,300 & 21,200 & 10 & 10.1 & 23.9 & 5.6 & 56 & 5.4 & 8.3 \\
\hline 3 & 22,400 & 19,800 & 12 & 12.5 & 27.5 & 3.6 & 41 & 7.1 & 9.2 \\
\hline 4 & 23,100 & 16,500 & 20.3 & 18.9 & 33.4 & 4.1 & 31 & 8.2 & 8.1 \\
\hline 5 & 23,700 & 20,200 & 20.7 & 23.7 & 38.1 & 4.9 & 38 & 9.2 & 5.4 \\
\hline 6 & 26,200 & 22,100 & 26 & 26.4 & 44.2 & 7.3 & 18 & 9.4 & 1 \\
\hline 7 & 27,600 & 21,400 & 34 & 27 & 46.5 & 4.9 & 22 & 9.3 & 0.8 \\
\hline 8 & 27,300 & 22,200 & 31.4 & 25.6 & 45.9 & 4.3 & 25 & 8.7 & 1 \\
\hline 9 & 24,200 & 27,500 & 30 & 21.2 & 43 & 4.5 & 28 & 7.8 & 1.3 \\
\hline 10 & 23,100 & 32,300 & 29.1 & 14.9 & 34.9 & 3.8 & 33 & 6.1 & 5.8 \\
\hline 11 & 21,400 & 27,100 & 24 & 15.8 & 25 & 3.7 & 75 & 4.7 & 6.1 \\
\hline 12 & 20,100 & 20,700 & 20 & 8.3 & 18.9 & 4.2 & 66 & 4 & 7 \\
\hline
\end{tabular}
model, Table 1.

Table 1

Summary of NJS and IWFBA

All factors and constants were recorded and reporting data for a year which obtained from Iraqi weather forecast - Basra Airport. It summarized in Table 1.

\section{Materials and methods}

Description of the STELLA model.

STELLA is software for graphic and dynamic simulation. It considers dynamics language because of STELLA is software for graphic and dynamic simulation [16]. The use of iconographic 
modelling techniques makes the model an elastic simulation tool with an easy for user interface so that change and calibrate can make easy. The effects of the changes can immediately view by user, thus reduces the time required to develop the model [17].

The developed model has seven state variables including $T_{W}$, the heat of input water to the tank. Conceptual diagrams of the heat gained from daily solar radiation, heat gained from pollutants removal rate, heat gained from radiation from wastewater surface, heat loss due to wastewater evaporation, heat loss due to surface diffuser and heat loss through tank walls are shown in the STELLA diagrams below. The major mechanisms for heat transfer dynamics in the system considered in this study were heat gained from pollutants removal rate. The growth of bacteria and consumption of pollutant by these bacteria can affect heat in tank. Temperature is not only a crucial factor affecting bacteria activity but also affects other physiochemical properties. These properties include dissolved oxygen saturation concentration, viscosity, and settling velocity [18].

The state variables, processes, parameters and auxiliary variables used in the model are shown in Fig. 3.

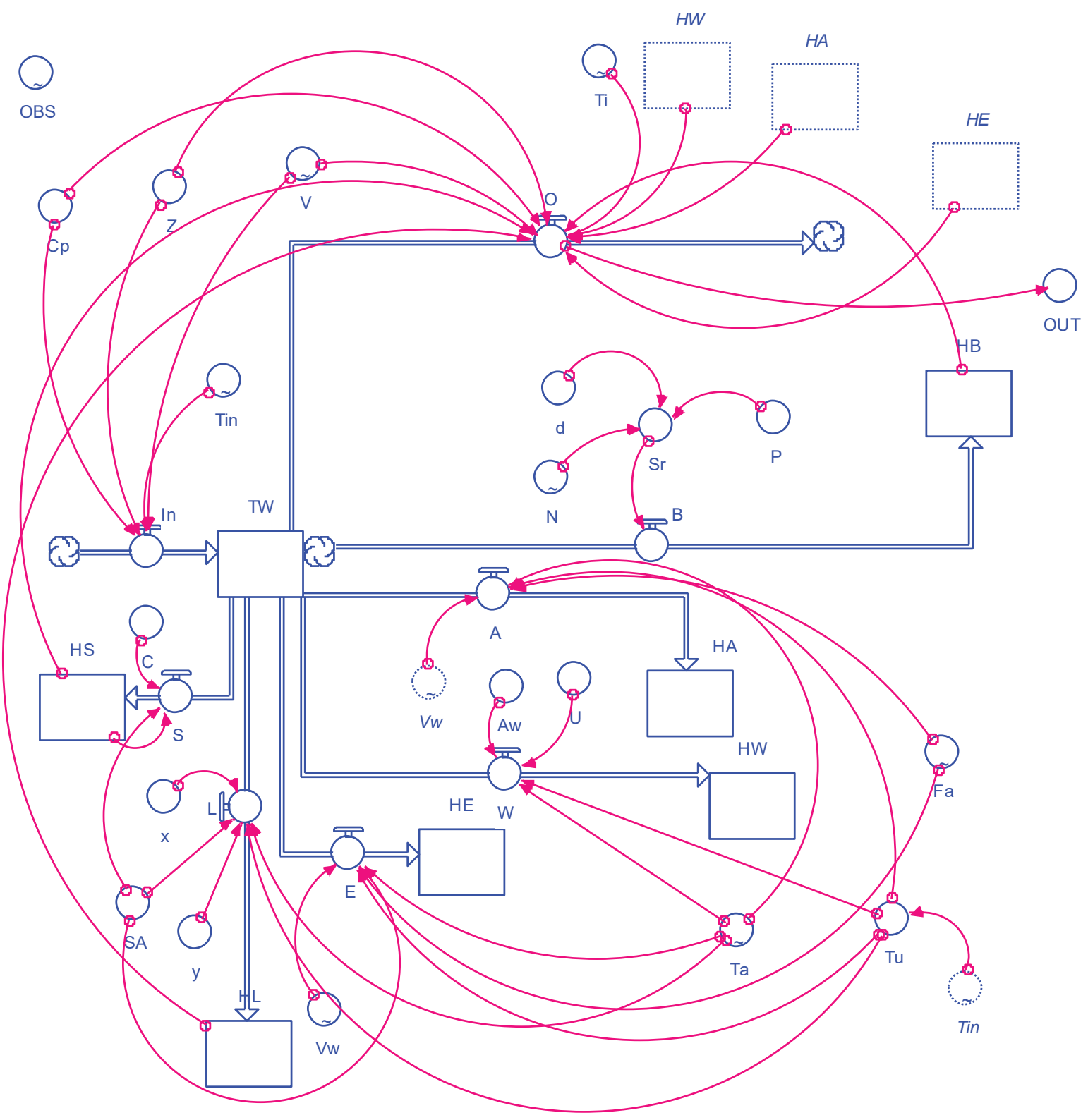

Fig. 3. A STELLA diagram of the wall temperature of aeration tank model 


\section{Results and discussion}

\section{1. Predication temperature wall of aeration tank using STELLA software}

The heat transfer model was simulated by the STELLA to predict aeration tank wall temperature. The input date for a year of 2018 with obtained data's from Hamdan wastewater treatment Station and Iraqi weather forecast- Basra Airport. Experiments were carried out for two periods using the first ninety days to attempt calibration as shown in Fig. 4. While the data for the rest of year was used for validation (Fig. 5). The input parameters were obtained from experimental measurements and theoretical calculations were used during the calibration (Table 1). The model was calibrated by trial and error where the simulation program was run repeatedly, adjustment of the key parameters within a reasonable range. The direction of this study is to calibrate into accomplished until predictions under similar conditions had good agreement with the selected experimental data.

Controlling aeration tank temperature is unfeasible, since heating or cooling is truly expensive; however, the reduction of extremes in range of temperature could occur when incorporating factors affecting aeration tank heat transfer in the design, improving overall process performance and reducing process variability. From Fig. 4, it has been found that the observed data were slightly lower than the simulated values during calibration period. However, this variation is highly insignificant when the mean percent error was $(26 \%)$ during this period.

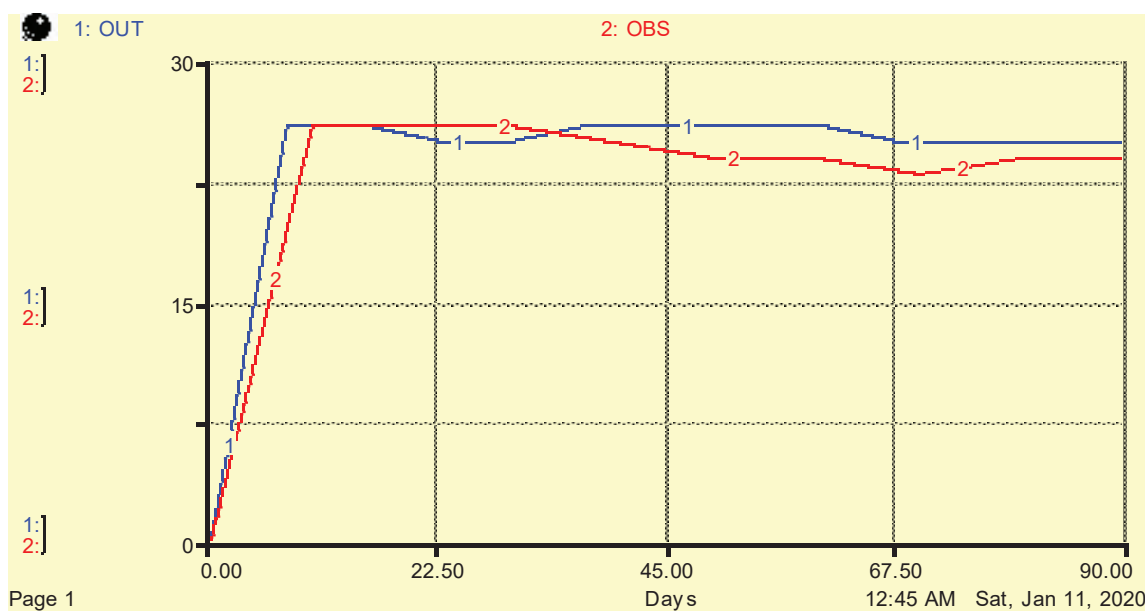

Fig. 4. Model calibration for the wall temperature of aeration tank

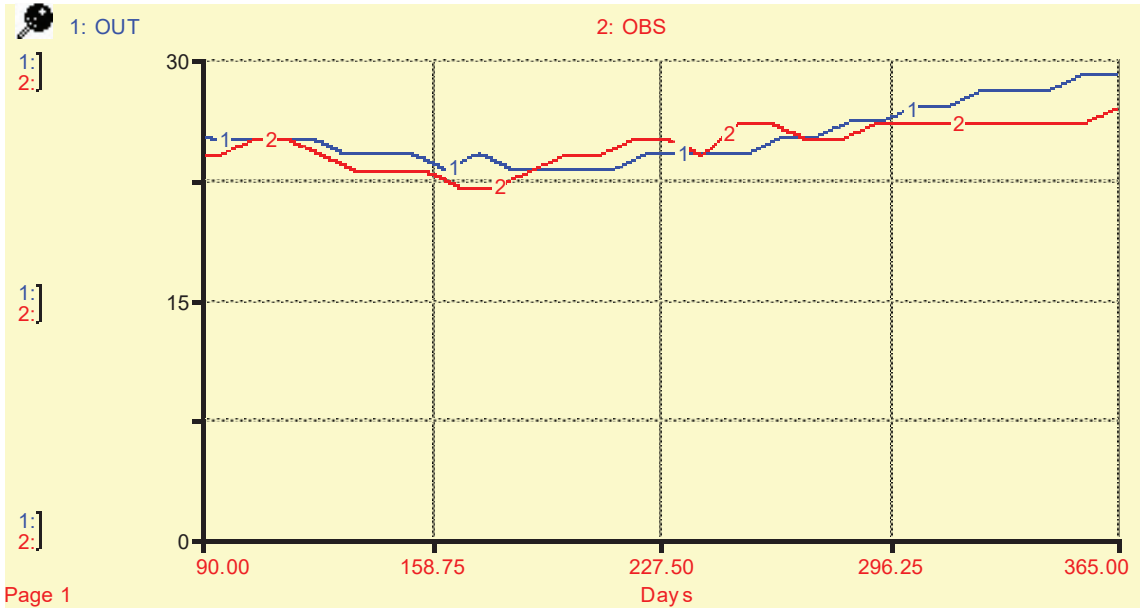

Fig. 5. Model validation for the wall temperature of aeration tank

It is worth noting that the validated data for the aeration tank wall temperature (Fig. 5) was quite close to the observed data, with mean percent error of $4.3 \%$. Despite the fact that the simulation data was higher than the observed data for the period of 316 to 365 . This slight fluctuation 
in the model simulation and the experimental data could be attributed to the fact that experimental error, or there is no growth of microbial within the aeration tank in this period.

This can contribute to heat production of wall temperature when the energy for microbial growth converts to heat energy [19]. Although that the mean percent error for this period was not exceed $8.7 \%$.

\section{2. Sensitivity analysis for model}

Once again, referring to the characteristics of the STELLA software, where it is possible to identify the most important parameters that give a clear impact on the behavior of the model. Now it is possible to define the most parameters that affect the model. The sensitivity of the model was tested using the five parameters, which were most likely to be important as shown in Table 2.

It is noted from the table above that the most influencing factor on its sensitivity to temperature is a parameter organic removal rate $\left(S_{R}\right)$, and then shows the effect of ambient air temperature $\left(T_{a}\right)$ and wind velocity $\left(C_{a}\right)$. Whereas, the model's sensitivity to impact by air relative humidity $(\varphi)$ and the wall effective area of the aeration tank $\left(A_{w}\right)$ is negligible.

After analyzing the sensitivity of the present model, it is now possible to make a comparison of the obtained results with a previous model result [6], for the purpose of indicating work reliability. As it was based on a previous study conducted to calculate the water temperature inside the aeration tank. Fig. 6 shows the comparison of present work with previous work.

Table 2

Sensitivity analysis $(S)$ for the selected parameters included in the model

\begin{tabular}{ccc}
\hline Parameters & $\boldsymbol{S}(\mathbf{+ 2 0} \%)$ & $\boldsymbol{S}(\mathbf{- 2 0} \%)$ \\
\hline$S_{R}$ & $1.64 \times 10^{-2}$ & $1.64 \times 10^{-3}$ \\
$T_{a}\left({ }^{\circ} \mathrm{C}\right)$ & $1.30 \times 10^{-4}$ & $2.50 \times 10^{-4}$ \\
$C_{a}(\mathrm{~m} / \mathrm{sec})$ & $5.70 \times 10^{-4}$ & $5.70 \times 10^{-4}$ \\
$\varphi(\%)$ & $7.88 \times 10^{-6}$ & $8.14 \times 10^{-6}$ \\
$A_{w}\left(\mathrm{~m}^{2}\right)$ & $4.02 \times 10^{-7}$ & $4.03 \times 10^{-7}$
\end{tabular}

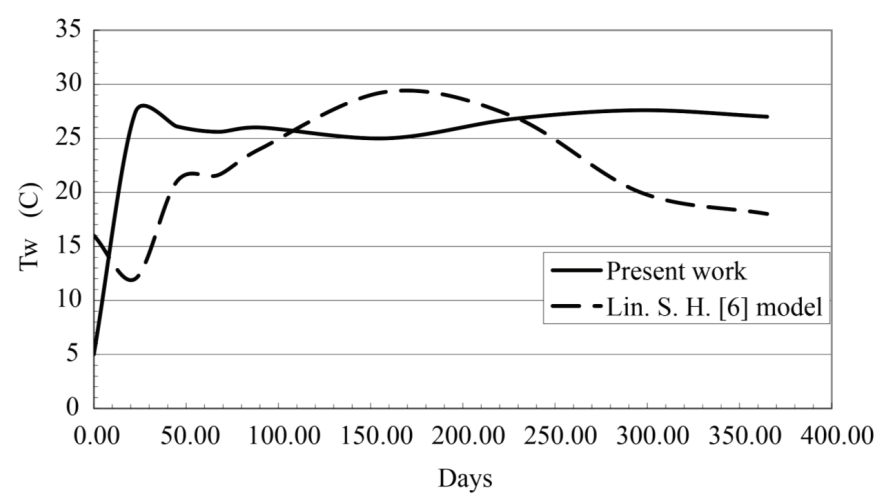

Fig. 6. Comparison present work with pervious work

It is possible through the Fig. 6, to prove that the behavior of the present work indicates more stable and appropriate with the previous work to maintain the temperature of the wall of the aeration tank.

\section{Conclusions}

In the present study, the present model modified of previous work and it was adopted for the purpose of predicting the wall temperature of the aeration tank of biological treatment system using the STELLA software. The dependence on the heat transfer models of biological treatment system after taking into consideration the climate values of Basra Governorate for the Hamdan Wastewater Treatment Plant. In terms of the model's sensitivity, the bacteria growth parameters was the most important factors especially dilution factor. 
After making model parameters simulations to give a clear prediction of the aeration tank wall temperature, here it can be concluded that the simulations give agreement results, especially after analyzing the sensitivity of the behavior of the curve trend, and therefore this model can be used to calculate the temperature of the wall of the biological tank. The model examined with a data for 12 months to verification the behavior of wall temperature. Then, a sensitivity of most important parameters was validated as shown in Table 2. The mean percentage error of the model is obtained about $8.7 \%$. While, the deviation between present work with previous work is about $26 \%$ as shown in Fig. 6.

\section{References}

[1] Masters, G. M. (1991). Introduction to environmental engineering and science. Prentice-Hall Int., 708.

[2] Grady, C. P. L., Daigger, G. T., Lim, H. C. (1999). Biological wastewater treatment. Marcel Dekker, Inc.

[3] Tchobanoglous, G., Burton, F. L., Stensel, H. D. (2002). Wastewater Engineering Treatment and Reuse. McGraw-Hill Inc., $553-555$.

[4] Wiesmann, U., Choi, S., Dombrowski, E. M. (2006). Fundamentals of Biological Wastewater Treatment. Wiley. doi: https:// doi.org/10.1002/9783527609604

[5] Raphael, J. M. (1962). Prediction of Temperature in Rivers and Reservoirs. Journal of the Power Division, 88 (2), $157-181$. doi: https://doi.org/10.1061/jpweam.0000338

[6] Lin, S. H. (1997). A heat transfer model for biological wastewater treatment system. Heat and Mass Transfer, 32 (4), $313-316$. doi: https://oi.org/10.1007/s002310050127

[7] Novotny, V., Krenkel, P. A. (1973). Evaporation and Heat Balance in Aerated Basins. AIChE Symposium Series, 70 (136), 150-159

[8] Bravo, H. R., Krajewski, W. F., Holly, F. M. (1993). State space model for river temperature prediction. Water Resources Research, 29 (5), 1457-1466. doi: https://doi.org/10.1029/93wr00099

[9] Groeger, A. W., Bass, D. A. (2005). Empirical predictions of water temperatures in a subtropical reservoir. Archiv Für Hydrobiologie, 162 (2), 267-285. doi: https://doi.org/10.1127/0003-9136/2005/0162-0267

[10] Doan, H., Lohi, A. (2009). Intermittent Aeration in Biological Treatment of Wastewater. American Journal of Engineering and Applied Sciences, 2 (2), 260-267. doi: https://doi.org/10.3844/ajeassp.2009.260.267

[11] Aguilar-López, R., López-Pérez, P. A., Peña-Caballero, V., Maya-Yescas, R. (2013). Regulation of an Activate Sludge Wastewater Plant VIA Robust Active Control Design. International Journal of Environmental Research, 7 (1), 61-68.

[12] Mohammed, A., Babatunde, A. O. (2017). Modelling heavy metals transformation in vertical flow constructed wetlands. Ecological Modelling, 354, 62-71. doi: https://doi.org/10.1016/j.ecolmodel.2017.03.012

[13] Thackston, E., Parker, F. (1972). Geographical Influence on Cooling Ponds. Journal (Water Pollution Control Federation), 44 (7), 1334-1351. Available at: http://www.jstor.org/stable/25037543

[14] Ali Morad, A. M., Shaker Al-Sayyab, A. K., Abdulwahid, M. A. (2018). Optimisation of tilted angles of a photovoltaic cell to determine the maximum generated electric power: A case study of some Iraqi cities. Case Studies in Thermal Engineering, 12, 484-488. doi: https://doi.org/10.1016/j.csite.2018.07.001

[15] Report On Data Collection Survey On Water Sector In Southern Iraq (2015). Japan International Cooperation Agency NJS Consultants CO. Available at: https://openjicareport.jica.go.jp/pdf/1000020477.pdf

[16] Forrester, J. W. (1997). Industrial Dynamics. Journal of the Operational Research Society, 48 (10), 1037-1041. doi: https:// doi.org/10.1057/palgrave.jors.2600946

[17] Jorgensen, S. E., Fath, B. D. (2011). Fundamentals of Ecological Modelling: Applications in Environmental Management and Research. Elsevier, 399.

[18] Russell, J. B. (1986). Heat production by ruminal bacteria in continuous culture and its relationship to maintenance energy. Journal of Bacteriology, 168 (2), 694-701. doi: https://doi.org/10.1128/jb.168.2.694-701.1986

[19] Lippi, S., Rosso, D., Lubello, C., Canziani, R., Stenstrom, M. K. (2009). Temperature modelling and prediction for activated sludge systems. Water Science and Technology, 59 (1), 125-131. doi: https://doi.org/10.2166/wst.2009.587

Received date 19.11.2020

(C) The Author(s) 2021

Accepted date 10.03.2021

Published date 31.03.2021

This is an open access article under the CC BY license (http://creativecommons.org/licenses/by/4.0).

How to cite: Morad, A. M. A., Mohammed, A. A., Sahi, A. O., Al-Sayyab, A. K. S. (2021). Temperature predict of aeration tank walls for biological wastewater treatment subsystem of hamdan station. EUREKA: Physics and Engineering, 2, 3-10. doi: https://doi.org/ 10.21303/2461-4262.2021.001706 